\title{
Physicochemical and biological quality of groundwater sources in Kadama Sub county, Kibuku District
}

\section{Abel Wilson Walekhwa ( $\square$ awalekhwa@berkeley.edu )}

Makerere University, School of Public Health

\section{Frederick Oporia}

Makerere University, School of Public Health

\section{Ali Halage}

Makerere University, School of Public Health

\section{Douglas Bulafu}

Makerere University, School of Public Health

\section{Aisha Nalugya}

Makerere University School of Public Health

\section{Arnold Tigaiza}

Makerere University School of Public Health

\section{Nagawa Bridget Tamale}

Makerere University School of Public Health

\section{Solomon Tsebeni Wafula}

Makerere University School of Public Health

\section{Achangwa Chiara}

Department of Public Health and Welfare, The graduate school, Konyang University 709 Ho, Myeongkok Medical Building, 158, Gwanjeodong-ro, Seo-gu, Daejeon, 35365, Republic of Korea.

\section{Jimmy Osuret}

Makerere University School of Public Health

\section{David Musoke}

Makerere University School of Public Health

\section{Research Article}

Keywords: Water quality, groundwater, turbidity, E. coli, Uganda

Posted Date: December 27th, 2021

DOI: https://doi.org/10.21203/rs.3.rs-1190899/v2 
License: (c) (i) This work is licensed under a Creative Commons Attribution 4.0 International License. Read Full License 


\section{Abstract}

\section{Introduction}

Water should comply with standard/regulatory physio-chemical and biological parameters to ensure that it is safe for domestic use. We therefore sought to assess the physico-chemical and biological quality of groundwater sources in Kadama subcounty, Kibuku district, Eastern Uganda.

\section{Methods}

A cross-sectional quantitative study was conducted. We collected water samples from twenty-three functional water sources. We assessed the turbidity, $\mathrm{pH}$ and presence of Escherichia coli (E. coli) using the turbidity meter, $\mathrm{pH}$ meter and membrane filtration technique, respectively. Furthermore, physical sanitary inspection of the water sources was done using a standard pretested observational checklist to assess existing risk factors.

\section{Results}

The majority, $69.5 \%$ of the water sources included in the study were boreholes, with about $43.5 \%$ of them from Nandere parish. Majority of the water sources $86.9 \%$ (20/23) had clogged/blocked drainage channels, about a third of water sources $60.9 \%$ (14/23) did not have fences/protection around them and majority of the water sources, $82.6 \%(19 / 23)$ had stagnated apron. Some water sources $8.7 \%(2 / 23)$ had open defecation around them. The water samples had a mean pH of 6.87 (SD 0.920 ) with $4.4 \%$ acidic, $86.9 \%$ normal/acceptable pH level and $8.6 \%$ in alkaline state. About two-thirds (65.3\%) of these water sources had turbidity levels less than 5 NTUs. In addition, boreholes had a better turbidity score of $81.2 \%$ $(13 / 16)$ compared to the water wells $71.4 \%(5 / 7)$. About half, $43.5 \%$ of the water sources were above the WHO recommended range of zero coliforms.

\section{Conclusions}

Some ground water sources had sanitary risk factors and significant levels of $E$. coli which makes them unfit for human consumption, though they can be used for other domestic purposes including washing clothes. This calls for urgent need to keep surrounding water sources clean and continuously disinfect drinking water from groundwater sources before human consumption.

\section{Introduction}

Water quality remains a significant public health concern globally, threatening human health, food production, ecosystem functions, and hindering economic growth (UNESCO, 2018). In 2017, approximately 785 million people did not have access to a basic drinking water service and at least 2 billion (over $25 \%$ of the world's population) did not have access to basic sanitation globally (UNICEF/WHO, 2019). Lack of sanitation facilities is one of the most significant forms of water pollution (UNESCO, 2018). The World Health Organization (WHO) estimates that over 2 billion people worldwide 
use a drinking water source contaminated with faeces (WHO, 2019), and this accounts for 485,000 diarrheal deaths each year (WHO, 2019). The burden of water safety and diarrhoeal diseases are highly pronounced in sub-Saharan Africa and partly contributes to low development as countries spend large sums of money managing such infectious diseases (Gwimbi et al., 2019).

Whereas Uganda has made substantial progress in increasing access to safe water and sanitation (WASH) service, millions of people, especially in rural areas and informal settings, still lack these basic services. Data shows that 21.9 million Ugandans lack access to safe drinking water, which represents more than half of the population (WaterAid, 2020). This is way below the Sustainable Development Goal (SDG) 6.1 target, which aims to achieve universal and fair access to safe and affordable drinking water for all (UN, 2021). Access to safe drinking and domestic water in terms of quantity and quality is essential in the prevention of water-related diseases such as cholera, typhoid, dysentery, trachoma among others (Bwire et al., 2020). Besides, it has the potential to decimate child malnourishment, help ease physical and mental under-development, and has profound socio-economic impacts (UNICEF, 2020, Ministry of Water and Environment, 2020).

Natural water exists in three forms, namely, ground water, rainwater and surface water (Bwire et al., 2020). Given the typically sparse infrastructure, remoteness, and economic constraints in rural settings in Uganda, groundwater is often the only alternative to scarce or polluted surface water. Most of the rural population relies on groundwater, dominantly from shared boreholes equipped with hand pumps (UPGro, 2020). 73 of the 98 (75\%) urban water supply systems in Uganda, and over $90 \%$ of the rural population depend on groundwater (UPGro, 2020). Natural ground water is usually of good quality, but can deteriorate because of inadequate source protection and poor resource management (Ramirez et al., 2010). Faecal coliforms and high concentrations of nitrates, iron, fluoride, and manganese have been found in some groundwater sources in Uganda (UPGro, 2020). The sources of contamination documented in literature include the disposal of sewage effluents, sludge and solid waste, septic tank effluent, urban runoff, landfill leachate and agricultural, mining and industrial practices (Ramirez et al., 2010, Al-Khatib and Arafat, 2009, Bwire et al., 2020, Owor et al., 2021). Therefore, it is imperative to routinely monitor groundwater quality.

Kibuku district. Yet, the district has previously experienced waterborne disease outbreaks, such as cholera (Bikala, 2016a). According to the health records at Kadama Health Centre III (KHC) and community scorecard project implemented by Makerere University School of Public Health in Kibuku district, there was continued reports of diarrhoeal diseases like typhoid, dysentery in this study area and there was loss of money in meeting medical bills for the local citizens (Ekirapa-Kiracho and Kakaire, 2016). The neighbouring secondary and primary schools have consistently reported low academic concentration as many students would get diagnosed with diarrhoeal diseases which in turn affects academic performance but also increased expenditure on the medical costs by the parents and school administration (George and Scott, 2016). Furthermore, there is documented evidence on high reliance on groundwater sources like boreholes, wells and springs by majority of Uganda's rural population (Kasozi et al., 2019). There was limited data on the physicochemical and biological quality in Kadama subcounty, 
Kibuku district. This study aimed to assess the physicochemical and biological parameters of groundwater sources and associated factors in rural Kibuku district, Uganda.

\section{Materials And Methods}

\section{Study area}

We conducted the study in Kadama sub county, Kibuku district in Eastern Uganda (see Appendix I). The place is in the lowland areas of river Manafwa banks and surrounded by seasonal swamps in the south. River Manafwa is known for its annual flooding, which affects quality of life of people in the neighbouring surroundings (Akumu, 2018). This sub county has six parishes of Dodoi, Nandere, Kabweri, Molokochomo, Kadama and Kenkebu. Kibuku district has a total population of 202,033, and majority of the population (60.3\%) is between the age of $0-17$ years, $51.8 \%$ females with about $65.4 \%$ of the district being water logged (UBOS, 2014). Most of the residents in the district are peasants and the main economic activity in the area is subsistence agriculture (Nekaka et al., 2021).

\section{Research design}

This was a cross-sectional quantitative study. The study applied both physical and laboratory-based techniques. We conducted the study in an area where people derive water for domestic purposes from different water sources. Purposive sampling was done to identify the twenty-three water sources out of 112 available water sources in the subcounty. This included 7 shallow water wells and 16 deep boreholes. This was informed by their functionality, number of community members served, type of the water source. Deliberate efforts were made to have a representation of the two mostly used water sources of wells and boreholes. We got water samples from twenty-three underground water sources. The underground water sources included boreholes and water wells. We conducted the study from January to March 2016.

\section{Data collection}

We collected two water samples in the midmorning hours from each of the 23 selected ground water sources in an interval of 30 minutes. Prior water sample collection, the outlets of boreholes were disinfected using cigarette lighter and then washed with distilled water to avoid contamination. Each sampling bottle was made of transparent glass and had a volume of $150 \mathrm{ml}$. Water was pumped and collected from the spout at a distance of about three inches to avoid contamination once it continually flowed. The samples were covered tightly and then stored in an icebox. Transportation of samples to the laboratory was done immediately after sampling within two hours to accredited district water quality analytics laboratory. The sample collection was done by experienced environmental health officers working in as health assistants and health inspectors in Kibuku district. At the water quality laboratory, we stored the samples at $40 \mathrm{C}$ in a refrigerator before analysis to prevent microbial growth. 
An observational checklist/ Sanitary Risk Score tool (Adopted from Risk of Contamination (ROC) WHO, 1997 was used (Kelly et al., 2020). The tool had various parameters that risk factors for water contamination at various ground water sources, such as location of pit latrine, availability of pit latrine within the 100 feet (30 meters) and open defecation.

\section{Physiochemical assessment}

Water $\mathrm{PH}$ and turbidity were measured onsite by observation using a $\mathrm{PH}$ meter and turbidity meter from Delaqua water kit (wag tech LTD) respectively (WAGTECH, 2021). The measurements were done three times in a minute's interval and the average reading was recorded. During data collection the study period was characterised by dry season (minimal rainfall, low humidity and high temperatures)

\section{Microbiological assessment}

The bacteriological analysis was done using a membrane filter technique. In this technique, a water sample of $100 \mathrm{ml}$ was incubated at $440 \mathrm{C}$ for 18 hours and later the number of total coliform units ( $E$. coli) counted using $\mathrm{X}^{10}$ hand lens to show microbial growth. Sterile membranes filters of pore $0.45 \mu \mathrm{m}$ (micrometres) diameter were used to filter the sampled water. Sterile adsorbent pads were placed on to the sterile culture plates with aid of the pad dispenser. Sterile lauryl-sulphate broth was used as a nutrient media to culture the bacteria and $2.5 \mathrm{ml}$ of it was drawn using the disinfected dropper onto the absorbent pad. The culture media was dropped at the centre of the absorbent pad, which later spread out uniformly. Using a cigarette flame lighter, the ends of the forceps were sterilised and were used to transfer the membrane filter onto the culture plate. The culture plates were covered and lauryl sulphate broth was used as a culture medium, labelled and placed inside the incubator, which was securely locked. Colonies which appeared as yellow clumps or spots on the filter paper were counted for each water source.

\section{Data analysis}

The data obtained from the analysis of the water samples was entered and cleaned in Ms Excel 2016. The data was there after analysed in Stata 13 (Stata Corp, Texas). Univariate analysis was conducted to obtain the statistics presented in tables and graphs as shown in the results section. The results of the improved water sources were checked for conformity with WHO drinking water guidelines 2011 and Uganda National Bureau of Standards (UNBS) US EAS 12.

These standards were agreed and considered a threshold as follows: E. coli should be zero $(0 / 100 \mathrm{mls})$ : turbidity of drinking water/portable water should be less than 5 Nephelometric Turbidity Units (NTUs) and the $\mathrm{pH}$ of drinking water should be between $6.5-8.5$, with that less than 6.4 taken to be acidic and that beyond 8.5 taken to be alkaline. We used these guidelines as a standard which determined the status of a particular type of water source.

\section{Ethical considerations}


The study received approval from Makerere University School of Public Health as part of the Bachelors in Environmental Health Sciences programme. We got administrative permission to conduct the study in the district from Kibuku district Administration. All the data collected was kept confidential and secured in a password protected computer only accessible by the study team.

\section{Results}

\section{Distribution of water sources}

The majority, $69.5 \%$ of the functioning water sources included in the study were boreholes. The majority, $43.5 \%$ of the groundwater sources were from Nandere parish (Table 1).

Table 1: Distribution of water sources

Parish/Zone Boreholes Wells

Frequency Percentage (\%) Frequency Percentage (\%)

\begin{tabular}{lllll}
\hline Kadama & 4 & 17.4 & 0 & 0 \\
\hline Dodoi & 2 & 8.7 & 5 & 21.7 \\
\hline Nandere & 10 & 43.5 & 0 & 0 \\
Nabunyere & 0 & 0 & 2 & 8.7 \\
Sub total & $\mathbf{1 6}$ & $\mathbf{6 9 . 5}$ & $\mathbf{7}$ & $\mathbf{3 0 . 4}$
\end{tabular}

\section{Physical conditions and immediate environment of the water sources}

The majority, $65.2 \%$ of the groundwater sources were greater than ten meters from households. The same fraction, $65.2 \%$ of the groundwater sources were greater than thirty meters away from the nearby latrine. The majority, $87.0 \%$ of the water sources had clogged/blocked drainage channels and majority, $82.6 \%$ of the groundwater sources had a clogged and stagnated apron (Table 2)

Table 2: Physical conditions and surrounding environment of the water sources 
Variable

Average distance from the nearest homestead (metres)

$<10$

8

34.8

$>10$

15

65.2

Distance from nearby latrine (metres)

$<30$

8

34.8

$>30$

15

65.2

Water source direction

Latrine situated uphill

6

26.1

Latrine situated downhill

17

73.9

Open defecation status

Absent

21

91.3

Present

2

8.7

Drainage

Unclogged drainage channels

3

13.1

Broken/clogged drainage channels

20

86.9

Protection of water source

Protected water source

9

39.1

Unfenced/unprotected water source

14

60.9

Stagnation of water spills/ water sources aprons

Stagnated water aprons

19

82.6

Un stagnated water aprons

4

17.4

Physico- chemical characteristics of the water sources 
The samples had a mean pH of 6.87 (SD 0.920). Majority, 65.3\% (15/23) of the groundwater sources had turbidity levels less than 5 NTUs. In addition, boreholes had a better turbidity score of $81.2 \%(13 / 16)$ compared to the water wells. Majority of the wells, $71.4 \%(5 / 7)$ had turbidity levels of over 5 NTUs. Majority $86.9 \%(20 / 23)$ of the samples had a PH of $6.5-8.5$ (Table 3$)$.

Table 3: Physiochemical parameter of the water sources

\begin{tabular}{lcc} 
Water sources turbidity, NTU & \multicolumn{2}{c}{ Frequency $(\mathrm{N}=23)$} \\
\hline$<5$ & 15 & 65.2 \\
\hline 5 & 8 & 34.8
\end{tabular}

Boreholes turbidity, NTU ( $n=16)$

\begin{tabular}{lcc}
\hline$<5$ & 13 & 81.2 \\
$>5$ & 3 & 18.8
\end{tabular}

Wells turbidity, NTU ( $n=7)$

\begin{tabular}{lcc}
\hline$<5$ & 5 & 71.4 \\
$>5$ & 2 & 28.6 \\
\hline pH (Mean =6.87, SD 0.920) & & \\
\hline 5.9 (Acidic) & 1 & 4.4 \\
\hline $6.5-8.5$ & 20 & 86.9 \\
$>8.5$ (Alkaline) & 2 & 8.6
\end{tabular}

\section{Microbiological characteristics of the groundwater sources}

Regarding presence of $E$. coli in the sampled water, more than half $56.5 \%(13 / 23)$ were within the WHO recommended range of zero coliforms, although 43.5\% (10/23) had coliforms (Table 5).

Table 5: Microbiological characteristics of the groundwater sources 


\section{E. coli content $(\mathrm{n}=23)$ Frequency $(\mathrm{N}=23)$ Percentage (\%)}

\begin{tabular}{lcc}
\hline $0 \mathrm{cfu} / 100 \mathrm{mls}$ & 13 & 56.5 \\
\hline$>0 \mathrm{cfu} / 100 \mathrm{mls}$ & 10 & 43.5
\end{tabular}

Furthermore, a cross-examination of results showed that $26.7 \%$ of water samples with recommended turbidity levels had $E$. coli whereas $75 \%$ of water samples with higher turbidity had $E$. coli

\section{Discussion}

Safe drinking water is important for the overall health and wellbeing of humankind. This study aimed at assessing the physicochemical and biological quality of groundwater sources in rural Kibuku district, Eastern Uganda. The study showed that close to two-thirds of the groundwater sources had turbidity levels of less than 5 NTUs. In addition, boreholes had a better turbidity score compared to the water wells; close to three quarters of the water wells had turbidity levels of over 5 NTUs. The mean pH was 6.87 (SD 0.920) and most of the samples had a pH within the WHO acceptable range for drinking water. Similarly, more than half of the samples had $\mathrm{E}$. coli content within the WHO recommended range of zero coliforms. A cross-examination further showed that three quarters of water samples with turbidity levels $>5 \mathrm{NTU} s$ had $E$. Coli as opposed to slightly more than a quarter of those with turbidity levels $<5$ NTUs. These findings could potentially inform policy makers, safe water advocates and project planners to always factor in the operation and maintenance of water sources in planning for any water source.

This study revealed that close to two-thirds (65.3\%) of groundwater sources had turbidity levels less than 5 NTUs. These meet the WHO recommended limits for turbidity of drinking water. However, there is a need for more sensitizations to ensure that consumers of water from water sources having turbidity above 5 NTUs treat it before consumption. Turbidity levels in this study are in similar ranges with those reported by other scholars, for example Rawat and Siddiqui, between 0.47 NTU-6.90 NTU (Rawat and Siddiqui, 2019) and Yasin et al., between 0.01-65.4 NTU (Yasin et al., 2015). Turbidity in drinking water is not only aesthetically unappealing but also harbours pathogens, which can cause gastric disorders and waterborne diseases (USGS, 2021). A cross-examination of our results indeed showed that three quarters $(75.0 \%)$ of water samples with higher than recommended turbidity levels had $E$. coli as opposed to only slightly more than a quarter $(26.7 \%)$ of those whose turbidity levels were within recommended limits. Presence of $E$. Coli in drinking water shows significant risk for waterborne disease outbreaks, like one already experienced in this area in 2016 (BIKALA, 2016b).

Water wells, however, were more turbid than boreholes. The majority (81.2\%) of the boreholes had turbidity levels less than 5 NTUs, while (71.4\%) of the water wells had turbidity levels over 5 NTUs. This could be because boreholes are better protected from surface runoff, dislodged sand, silt or clay, among others compared to water wells; especially those in Eastern Uganda which are commonly dug wells, 
shallow and not changed for protection from contaminants like surface runoff and storm water. Some of the shallow wells at times have their water shared between humans and livestock which contaminate and make it turbid. This is could also be attributed to the fact this is a rural setting where mostly practiced economic activity is agriculture around such water sources. During rainy seasons the tiled soils find their ways to the unprotected water sources thus leading to contamination making the water turbid. These findings are quite similar to those of Adetinuke and colleague (2016) who reported 0.00 FTU for boreholes and between 6.25 and 45.86 FTU for water wells (Adetinuke and Oshunrinade, 2016). The discrepancy in our borehole water turbidity and theirs could, however, be because of the variation in mineral composition of soils surrounding the sampled water sources. This finding calls for urgent fencing or protection of such water sources which will protect them from surface run off. This could be a community-led initiative through the support of district or local council guidance.

The study further revealed that the majority (86.9\%) of the samples had a pH of $6.5-8.5$, with the mean $\mathrm{pH}$ being 6.87. Therefore, most water sources are within the $\mathrm{WHO}$ recommended $\mathrm{pH}$ for drinking water. However, there is concern for some water sources which had acidic ranges and alkaline ranges since these affect the acceptability of such water by the community members. These findings corroborate those of a study by Bernard and Ayeni who's pH ranged between 6.3-8.2 (Bernard and Ayeni, 2012). Our mean $\mathrm{pH}$ however, was quite higher than that reported by Omuna and colleague $(5.65 \pm 0.071)$ on a study conducted in Kumi Town council, Eastern Uganda (Omuna and Eniru, 2016). This dissimilarity could be explained by the difference in settings from which the samples were picked. Kumi town council is a more urban setting with a high population density and several activities through which wastewater is generated. Through seepage, wastewater, which contains detergents and soap-based products, can cause a water source to become basic. Other scholars have reported varying $\mathrm{PH}$ ranges to ours for example Asadullah and colleagues, 3.2-8.7 (Asadullah et al., 2013), Yasin and colleagues, 5.64-8.14 with a mean of 6.72 (Yasin et al., 2015). There is need to identify the ions which could be responsible for acidic levels and potential deionisation efforts instituted.

In this study, more than half $(56.5 \%)$ of sampled water showed E. coli content were within the WHO recommended range of zero coliforms although $43.5 \%$ had coliforms. This finding could be associated with the open defecation that was observed in some water sources. Also, the unprotected water sources is liable to faecal contamination through surface water run off but also potentially nearby latrines which could lead to ground water contamination. Faecal coliforms and $E$. coli presence indicates contamination of water supplies and signifies an increased risk of presence of waterborne pathogens. Treatment of drinking water from such sources should be emphasized and a surveillance system should be put in place to monitor and control threats of disease outbreaks. This finding calls for urgent sensitization of community members to always treat drinking water in bid to disinfect it from any microbial contamination which could lead to diarhoeal diseases in this community. The district leadership and government of Uganda official need to prioritize water treatment schemes in such rural settings in bid to protect the lives of the community members. In addition, more research needs to be done to establish counts of total and faecal coliforms in these water sources as well as factors associated with the presence of coliforms in some of the water sources.

Page $11 / 16$ 
The observed sanitary risks at majority of the water sources shows a gap in community level involvement in the operation and maintance of these water sources. These observed gaps could be associated with the ground water contamination but less appreciation of the hazards this causes by the community members. These findings are in agreement with other studies conducted in Kenya, Nepal, Bangladesh and South Africa which showed that their water sources under investigation had dirty surroundings which could contaminate the water from such sources (Misati et al., 2017, Alvarez et al., 2009).(Rayamajhi et al., 2014). This calls for massive sensitization by key stakeholders involved in providing water to the communities. This is aimed at increasing awareness and changing the attitude which will help to address water safety needs.

Our study had strengths arising from the laboratory analysis of the water collected coupled with quality tests that were conducted at the regional reference water quality laboratory in Mbale. We also picked samples from the entire geographical location of the study area which enabled understanding of water quality from the entire sub county. We worked with a team of competent research assistants who helped in water sampling a pre-requisite to getting real-time and representative results. We also the standard water source surveillance (ROC) designed by the WHO to guide countries in assessing the quality of water. However, our study also had notable limitations; this was a student led research study of the corresponding author with a small budget which limited the number of water sources samples making the power of our study low. We only focussed on the quantitative methods which made us to lose a lot of qualitative information which would use to understand issues of poor sanitation around water sources. We did not detail the ions responsible for the acidity or alkalinity of the water sources yet this would inform the water treatment methods rational to the ions discovered. Lastly, this study was only done in one of the sub counties among the 16 sub counties in the district and this could not provide entire picture of the region. We recommend another study to be conducted in the entire district employing both qualitative and quantitive methods to understand more factors associated with the quality of water in this area.

\section{Conclusion}

A number of water sources had bacteriological contamination ( $E$. coli) with more than a quarter of those with turbidity levels $<5 \mathrm{NTUs}$. Close to two-thirds of the groundwater sources had turbidity levels $<5 \mathrm{NTUs}$, which lies within WHO recommended limits. Boreholes, however, had a better turbidity score compared to the water wells. The mean $\mathrm{pH}$ was 6.87 and most of the samples had a pH within the WHO acceptable range for drinking water. Water sources in Kadama sub county are not very safe for human consumption and treatment is highly recommended before drinking.

\section{Abbreviations}

\section{E. coli - Escherichia coli}

RAs - Research Assistants 
VHTs- Village Health Teams

WHO - World Health Organization

$\mathrm{PH}$ - Potential of Hydrogen

NTU - Nephelometric Turbidity Units

\section{Declarations}

\section{Consent for publication}

Not applicable

\section{- Availability of data and materials}

The datasets generated and/or analysed during the study are not publicly available but are available from the corresponding author on reasonable request.

\section{- Competing interests}

The authors declare no competing interest.

\section{- Funding}

The study was funded by the principal investigator

\section{- Authors' contributions}

JO and AWW conceived and designed the study; AWW funded the study; JO, DM, FO provided technical guidance. JO supervised the work. AWW, JO, DB, NBT took part in data analysis and interpretation of the data. AWW, DB, AH, AT, AN, AC drafted and wrote the manuscript. JO, DM, and FO reviewed the final manuscript. All the authors reviewed and approved the final manuscript.

\section{- Acknowledgement}

We thank community health workers, and administrative staff of Kibuku district, Uganda for the technical support given to the team during the study. We appreciate the technical input in manuscript editing and writing from Brenda Nakazibwe, Mary Nantongo, Faith Rachel Mirembe, Lydia Namakula Nabawanuka.

\section{References}

ADETINUKE, A. \& OSHUNRINADE, O. 2016. Comparison of water quality from boreholes and hand-dug wells around and within the University of Lagos, Lagos, Nigeria. 
AKUMU, J. 2018. Factors Associated with Uptake of Floods Early Warning Information in Butaleja District, Eastern Uganda.

AL-KHATIB, I. A. \& ARAFAT, H. A. 2009. Chemical and microbiological quality of desalinated water, groundwater and rain-fed cisterns in the Gaza strip, Palestine. Desalination, 249, 1165-1170.

ASADULLAH, AND, K. \& KHAN, S. 2013. PHYSICO-CHEMICAL PROPERTIES OF DRINKING WATER AVAILABLE IN EDUCATIONAL INSTITUTES OF KARACHI CITY. Journal of Science, Technology and Development, 32, 28-33.

BERNARD, E. \& AYENI, N. 2012. Physicochemical analysis of groundwater samples of Bichi local government area of Kano State of Nigeria. world Environment, 2, 116-119.

BIKALA, M. 2016a. Cholera Claims 1, 52 Admitted in Kibuku [Online]. Uganda Radio network. Available: https://ugandaradionetwork.com/story/cholera-claims-1-56-admitted-in-kibuku [Accessed 6th January 2021 2021].

BIKALA, M. 2016b. Cholera Claims 1, 52 Admitted in Kibuku [Online]. Uganda Radio network. [Online]. Available: https://ugandaradionetwork.com/story/cholera-claims-1-56-admitted-in-kibuku [Accessed 3/07 2021].

BWIRE, G., SACK, D. A., KAGIRITA, A., OBALA, T., DEBES, A. K., RAM, M., KOMAKECH, H., GEORGE, C. M. \& $\mathrm{ORACH}, \mathrm{C}$. G. 2020. The quality of drinking and domestic water from the surface water sources (lakes, rivers, irrigation canals and ponds) and springs in cholera prone communities of Uganda: an analysis of vital physicochemical parameters. BMC Public Health, 20, 1128.

GWIMBI, P., GEORGE, M. \& RAMPHALILE, M. 2019. Bacterial contamination of drinking water sources in rural villages of Mohale Basin, Lesotho: exposures through neighbourhood sanitation and hygiene practices. Environmental health and preventive medicine, 24, 1-7.

KELLY, E. R., CRONK, R., KUMPEL, E., HOWARD, G. \& BARTRAM, J. 2020. How we assess water safety: A critical review of sanitary inspection and water quality analysis. Science of The Total Environment, 718, 137237.

MINISTRY OF WATER AND ENVIRONMENT 2020. Water and Environment Sector Performance Report 2020.

NEKAKA, R., OBOTH, P., NTEZIYAREMYE, J., GAVAMUKULYA, Y., SSENYONGA, L. V. \& IRAMIOT, J. S. 2021. Sero prevalence and factors associated with Helicobacter pylori infection in a rural population in Eastern Uganda a community cross sectional study. Primary Health Care: Open Access, 11, 1-9.

OMUNA, D. \& ENIRU, E. I. 2016. Assessment of Portable Water Quality in Kumi Town Council, Eastern Uganda, Munich, GRIN Verlag,. 
OWOR, M., MUWANGA, A., TINDIMUGAYA, C. \& TAYLOR, R. G. 2021. Hydrogeochemical processes in groundwater in Uganda: a national-scale analysis. Journal of African Earth Sciences, 175, 104113.

RAMIREZ, E., ROBLES, E., GONZALEZ, M. E. \& MARTINEZ, M. E. 2010. Microbiological and physicochemical quality of well water used as a source of public supply. Air, Soil and Water Research, 3 , ASWR. S4823.

RAWAT, R. \& SIDDIQUI, A. 2019. Assessment of Physiochemical Characteristics of Drinking Water Quality in Allahabad Metropolitan City, India. The Oriental Anthropologist, 19, 121-135.

UBOS. 2014. National Census Main Report (2014) - Uganda Bureau of Statistics [Online]. Available: https://www.ubos.org/wpcontent/uploads/publications/03_20182014_National_Census_Main_Report.pdf [Accessed 7/2/2021 2021].

UN. 2021. Sustainable Development Goals: Goal 6: Ensure access to water and sanitation for all [Online]. Available: https://www.un.org/sustainabledevelopment/water-and-sanitation/.

UNESCO. 2018. The global water quality challenge \& SDGs [Online]. Available: https://en.unesco.org/waterquality-iiwq/wq-challenge [Accessed 26th June 2021].

UNICEF. 2020. Water, sanitation and hygiene (WASH)--Increasing access to safe drinking water, improved sanitation and hygiene practices [Online]. Available: https://www.unicef.org/uganda/what-we-do/wash.

UNICEF/WHO 2019. Progress on household drinking water, sanitation and hygiene 2000-2017: special focus on inequalities, United Nations Children's Fund (UNICEF) and World Health Organization (WHO).

UPGRO. 2020. African Ground Water [Online]. [Accessed 27th June 2021].

USGS. 2021. Turbidity and water[Online]. Available: https://www.usgs.gov/special-topic/water-scienceschool/science/turbidity-and-water?qt-science_center_objects=0\#qt-science_center_objects [Accessed 04/07 2021].

WAGTECH. 2021. Water Analysis Technologies [Online]. WagTech website: Wagtech. Available: https://www.palintest.com/product-categories/wagtech/ [Accessed 7th July 2021 2021].

WATERAID. 2020. Water, Sanitation and Hygiene, Uganda [Online]. Available: https://www.wateraid.org/where-we-work/uganda [Accessed 27th June 2021].

WHO. 2019. Drinking-water[Online]. Available: https://www.who.int/news-room/factsheets/detail/drinking-water [Accessed 26th June 2021].

YASIN, M., KETEMA, T. \& BACHA, K. 2015. Physico-chemical and bacteriological quality of drinking water of different sources, Jimma zone, Southwest Ethiopia. BMC Research Notes, 8, 541. 
Alvarez, J. L., Gil, R., Hernández, V. \& Gil, A. 2009. Factors Associated With Maternal Mortality In SubSaharan Africa: An Ecological Study. BMC Public Health, 9, 1-8.

Ekirapa-Kiracho, E. \& Kakaire, A. 2016. Saving Money, Saving Lives: Community Saving Groups Lead To Improvements In Maternal And Newborn Health Care In Uganda.

George, A. \& Scott, K. 2016. Unlocking Community Capability: Key To More Responsive, Resilient And Equitable Health Systems.

Kasozi, K. I., Namubiru, S., Kamugisha, R., Eze, E. D., Tayebwa, D. S., Ssempijja, F., Okpanachi, A. O., Kinyi, H. W., Atusiimirwe, J. K. \& Suubo, J. 2019. Safety Of Drinking Water From Primary Water Sources And Implications For The General Public In Uganda. Journal Of Environmental And Public Health, 2019.

Misati, A. G., Ogendi, G., Peletz, R., Khush, R. \& Kumpel, E. 2017. Can Sanitary Surveys Replace Water Quality Testing? Evidence From Kisii, Kenya. International Journal Of Environmental Research And Public Health, 14, 152.

RAYAMAJHI, R., BUDHATHOKI, S., GHIMIRE, A., NIRAULA, S., KHANAL, V., NEUPANE, B., SHAKYA, B. \& POKHAREL, P. 2014. A study on sanitary and hygiene practices in Chungwang VDC of Dhankuta District, Eastern Nepal. Journal of Chitwan Medical College, 4, 20-24.

\section{Supplementary Files}

This is a list of supplementary files associated with this preprint. Click to download.

- Appendix.docx 